\title{
Moulds in biodeterioration of technical materials
}

\author{
BEATA GUTAROWSKA \\ Technical University of Lodz, Biotechnology and Food Science, Institute of Fermentation Technology and \\ Microbiology, 171/173 Wólczańska Street, 90-924 Łódź, Poland \\ E-mail: beata.gutarowska@p.lodz.pl
}

Abstract

Moulds are microorganisms which play the key role in biodeterioration of technical materials which results from their physiological features and metabolism. Technical materials constitute the source of carbon and energy (wood, paper, textiles, fuels, leather) or the surface for fungal growth (bricks, stone, metal, glass). Moulds characterized by a high biodeterioration activity - enzymatic and acidic, belong mainly to the following genera: Aspergillus, Penicillium, Trichoderma, Cladosporium, Paecilomyces and Chaetomium. Members of some taxa (besides the aforementioned also e.g. Stachybotrys, Alternaria, Epidermophyton, Microsporum, Scopulariopsis, Trichophyton) growing on technical substances and producing allergens and mycotoxins cause health hazards. Therefore, basing on the knowledge about conditions for mould development and biodeterioration mechanisms, we should appropriately preserve materials against mould growth. Looking for new disinfection methods safe for technical substances in order to inhibit mould growth is also important. Protective applications of biocides should be limited only to materials most sensitive to biodeterioration (paper, textiles, fuels, paints). On the one hand we should take into consideration environmental protection, on the other production of durable, biodegradable materials ensuring the product life cycle.

KEY WORDS: moulds, biodeterioration, technical materials, biocides, disinfection

\section{Introduction}

Biodeterioration of technical materials (destruction caused by the activity of organisms) causes serious economic losses resulting from the disturbance of their properties, disasters and accidents in industry and health hazards when potential and actual pathogens grow on various surfaces.

There are many described examples of microbial accidents during production, storage and usage of materials in the textile, paper, building and other industries (Zyska 2001).

It was estimated that the economic losses caused by microbial deterioration each year amounted to $2 \%$ of Gross 
National Product (Zyska \& Żakowska 2005). Based on the data of GUS (Central Statistical Office) for Poland in 2013 this value was $3.2 \times 10^{10}$ PLN. Moreover, it is impossible to estimate the loss of culture heritage when we take into account destruction of historical objects or the health threat to workers and users of materials.

Moulds are dominant and the most important microorganisms in biodeterioration of technical materials considering their ubiqiuty and the amount of damage and threats. However, we must remember that some technical substances are often exposed to bacteria, algae, insects, higher fungi from lichenized Ascomycota and Basidiomycota. However, development of actual damaging factors depends on the material composition and environmental conditions. In the case of wood, higher fungi and insects are responsible for its destruction; bricks and stones are destroyed mainly by algae and cyanobacteria, when they have access to light.

Significance of moulds in biodeterioration of technical materials results from their physiological features and metabolism (Fig. 1). Oligotrophic character and expansion in natural environments are the most important. A wide spectrum of produced enzymes and metabolites enables them to colonize many environments and to use almost every organic substrate. Moreover ease of spreading, different ways of propagation, creation of spores, production of secondary metabolites (antibiotics, toxins) to inhibit the growth of other organisms and high tolerance of unfavorable environmental conditions (UV, disinfection, low $\mathrm{pH}$, humidity) are features which facilitate colonization of technical materials and make fungi difficult to eliminate.

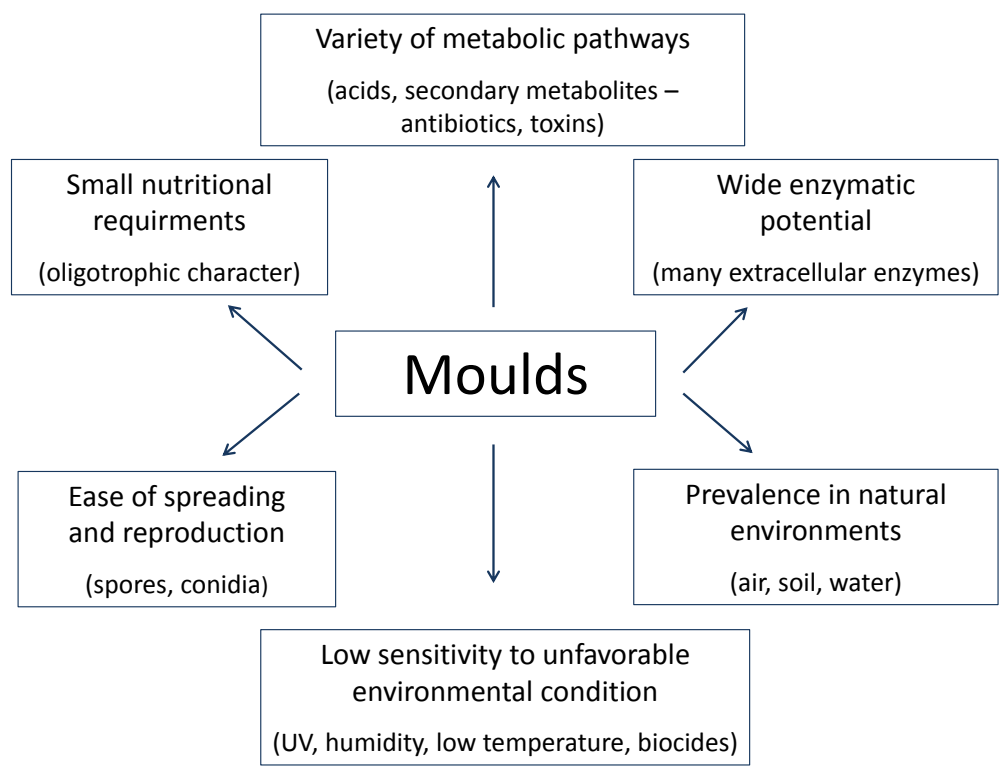

Figure 1. Mould physiological features which allow biodeterioration 
High humidity of the environment (optimum $\mathrm{a}_{\mathrm{w}}>0.9$ ) and access to oxygen (moulds are aerobic organisms growing on surfaces) are factors facilitating their development. However, well-known xerophilic moulds from genera Aspergillus and Penicillium are able to grow at low substrate humidity (aw = 0.8 ) and at low relative humidity of the air $\mathrm{RH}=60 \%$; also production of spores in soil at low oxygen concentration was observed (numerous mould species were isolated from historical objects from tombs).
In the view of the above facts, possibility of limiting the adverse influence of moulds on technical materials should be considered. This review presents the literature addressing the following issues:

1. which technical materials are most exposed to mould development?

2. which moulds have the greatest biodeterioration potential?

3. whether and when disinfection of mouldy technical materials or antifungal materials should be applied?

\section{Mechanisms of mould-induced biodeterioration of technical materials}

There are two mechanisms of technical material biodeterioration biological degradation and biological corrosion (Zyska \& Żakowska 2005). Materials of the natural origin - wood, paper, fabrics, leather, petroleum products, oils, fuels, paints, rubber are mould-degradable (biodegradation). Moulds belonging to genera Aspergillus, Penicillium, Alternaria, Cladosporium, Trichoderma and others are producers of extracellular enzymes which degrade polymers into monomers using them as a source of carbon and energy.

Enzymatic profiles of moulds change according to biochemical induction of environment, in which they grow. The same species growing on carton-gypsum board or on mortar produces different enzymes (Gutarowska 2010). Total mineralization occurs very quickly on organic substances containing cellulose: cotton and paper (e.g. cotton stored in the soil for a few weeks at high humidity becomes degraded by moulds to $\mathrm{CO}_{2}$ and $\mathrm{H}_{2} \mathrm{O}$ ). Five-week experiment concerning fuel degradation with Cladosporium species showed important changes in the fuel chemical composition leading to the reduction in its octane number (Zyska \& Żakowska 2005). Technical materials like cotton, paper, carton-gypsum board, emulsion paints are most sensitive to mould development and biodegradation processes. Biocorrosion, resulting from chemical reactions between organic acids produced by fungi and technical material is the other mechanism of mouldtriggered degradation. This process causes decay of mineral surfaces of building materials (stone, brick, mortars, concrete), metal and glass (Krumbein 1988, May et al. 1993). Moulds belonging to Aspergillus and Penicillium produce significant amounts of organic acids such as citric, oxalic, malic and others which react with elements ( $\mathrm{Al}$, $\mathrm{Mg}, \mathrm{Fe}, \mathrm{Si}, \mathrm{Mn}$ ), cause material demineralization, production of soluble salts or the deposition of insoluble salts forming a layer on surfaces e.g. calcite (Cwalina 2003). Additionally, mycelium damages the material mechanically due to hyphae $3-5 \mathrm{~cm}$ penetration into it. All this results in loss of cohesion and increase in porosity, furthermore organic acids buffer the materials, making them susceptible to halophilic bacteria which intensifies destruction. The type of material is crucial, because it stimulates the production of specific organic acids (Gutarowska \& Czyżowska 2009). 
Among inorganic surfaces stone, brick, mortar are sensitive to mould growth under high moisture conditions and presence of contaminants.

\section{Moulds involved in the biodeterioration of technical materials}

The chemical composition of technical materials determines the development of different moulds (Table 1). Moulds from genera Aspergillus and Penicillium (called moulds of warehouses) are most common. High air humidity and favorable chemical composition of the material make these fungi not only able to deteriorate many substrates, but also produce secondary metabolites (mycotoxins, volatile compounds) that are toxic to animals (Larssen \& Frisvad 1994, Singh 2005). Some allergic aspergilli and penicillia found growing in damp buildings and present in indoor air were also isolated from lung specimens at autopsy (Flannigan \& Miller 1994).

Technical materials containing cellulose (wood, paper, cotton, linen) or its derivatives in the form of esters, ethers (emulsion paints) are degraded by fungi belonging to the genera Aspergillus, Penicillium, Chaetomium, Trichoderma, Cladosporium, Alternaria and others.

Cellulose substrates used in buildings readily taking up water from environment (wallpaper, carton-gypsum boards) can provide a source of nutrients necessary for growth of Stachybotrys chartarum, which create serious mycotoxin hazard in buildings (Flannigan \& Miller 1994). A number of macrocyclic trichothecenes (verrucarins, satratoxins, trichoverrins) were found in colonized materials. Paper and wood are easily degraded by the cellulase enzyme complex; the problems associated with the development of moulds during production of paper in paper mills, as well as during storage of paper in archives and libraries are described in literature (Zyska \& Żakowska 2005). The development of moulds in paper factories begins already during storage of raw material (wood, paper) and production of cellulose pulps. It has been shown that unbleached mass produced from recycled substrates is more contaminated than the unbleached pulp originating from trees (in the bleaching process a biocide, titanium dioxide, is added). The mould growth was also observed on production machinery in the form of biofilms and pulp tanks (Gutarowska \& Cichocka 2009). Degradation of paper in archives and libraries mainly by Aspergillus and Penicillium is a serious problem, especially under the conditions of high humidity of paper/air, such as disasterrelated flooding of warehouses or during storage in uncontrolled microclimate (periodical humidity of the air $\mathrm{RH}<70 \%$ ). Under such conditions, development of fungi on books is possible; there is also a hypothesis that moulds are involved in the formation of a 'Foxing' phenomenon (orange-brown small spots on paper) common in nineteenth century books (Florian \& Manning 2000, Strzelczyk 2001). Numerous examples of mouldinduced destruction of historical objects are also described, including paintings, monuments, paper, leather and textiles (Strzelczyk 2001, Strzelczyk et al. 2003, Florian 2004). The primary reasons of their biodegradation include mechanical damage, an organic nature, age and the presence of contaminants.

Materials containing proteins (wool, leather) are colonized by Mucor, Rhizopus, Aspergillus, Penicillium, Cladosporium, Acremonium, Alternaria fungi and other taxa with proteolytic properties. What is more, in materials 
containing proteins such as keratin and collagen human pathogens such as Epidermophyton, Microsporum, Scopulariopsis, Trichophyton can grow. Many species of these genera cause mycoses and are classified to the class 3 of Biosafety Level (BSL) in terms of risk to human health. They pose a serious threat to people working in tannery, leather and wool product warehouses, as well as technicians, people exposed to fungi in mouldy buildings or users of these materials (Singh 2001).

Table 1. Moulds participating in biodeterioration of technical materials.

\begin{tabular}{|c|c|c|}
\hline Technical & Fungal taxon* & Reference \\
\hline Wood & $\begin{array}{l}\text { Aspergillus sp. (A. brasiliensis), Chaetomium } \\
\text { globosum, Penicillium sp., Trichoderma viride }\end{array}$ & Fojutowski 2003 \\
\hline Paper & 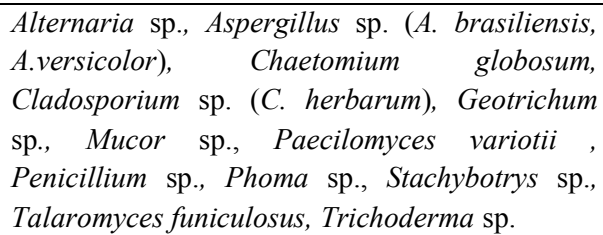 & $\begin{array}{l}\text { Woźniak \&Tymińska 2003, } \\
\text { Zyska \& Żakowska } 2005\end{array}$ \\
\hline Textiles & 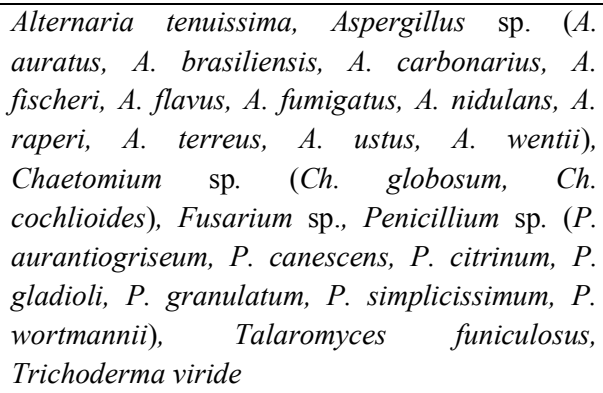 & $\begin{array}{l}\text { Szostak-Kot 2001, 2003, } \\
\text { Abdel-Kareem 2009, Błyskal } \\
\text { \& Syguła-Cholewińska } 2001\end{array}$ \\
\hline Leather & $\begin{array}{l}\text { Acremonium sp., Alternaria sp. (A. alternata), } \\
\text { Aspergillus sp. (A. brasiliensis, A. flavus, A. } \\
\text { fumigatus, A. terreus, A. versicolor, A. wentii), } \\
\text { Chaetomium globosum, Chrysosporium sp., } \\
\text { Cladosporium sp. (C. cladosporioides, C. } \\
\text { carrioni), Epidermophyton floccosum, Fusarium } \\
\text { sp. (F. oxysporum), Haematonectria } \\
\text { haematococca, Microascus brevicaulis, } \\
\text { Microsporum canis, Mucor plumbeus, } \\
\text { Paecilomyces variotii, Penicillium sp. (P. } \\
\text { aurantiogriseum, P. citrinum, P. glabrum, P. } \\
\text { ochrochloron, P. purpurogenum, P. verrucosum), } \\
\text { Rhizopus stolonifer, Spicaria sp., Scopulariopsis } \\
\text { sp. , Stemphylium sp., Syncephalastrum } \\
\text { racemosum, Talaromyces ruber, Thamnidium } \\
\text { elegans, Trichoderma sp., Trichophyton sp. (T. } \\
\text { mentagrophytes, T. rubrum, T. tonsurans) }\end{array}$ & $\begin{array}{lr}\text { Orlita } & \text { 2001, Strzelczyk et } \text { al. } \\
2003, \quad \text { Perkowski } & \& \\
\text { Goździecki } & 2003, \\
\text { Falkiewicz-Dulik 2003 }\end{array}$ \\
\hline
\end{tabular}

\footnotetext{
* Fungal taxa according to Index Fungorum (www.indexfungorum.org, accessed 22.07.2014)
} 


\begin{tabular}{|c|c|c|}
\hline $\begin{array}{l}\text { Technical } \\
\text { material }\end{array}$ & Fungal taxon* & Reference \\
\hline $\begin{array}{l}\text { Petroleum, oil, } \\
\text { fuels }\end{array}$ & $\begin{array}{l}\text { Alternaria sp., Amorphotheca resinae, } \\
\text { Aspergillus sp. (A. fumigatus, A. versicolor, A. } \\
\text { ustus), Fusarium sp., Humicola sp., } \\
\text { Paecilomyces variotii, Penicillium sp. }(P . \\
\text { canescens, } \text { P. spinulosum), Sarocladium strictum }\end{array}$ & Kwiatkowska 2003 \\
\hline Paints & Aureobasidium pullulans, Paecilomyces variotii, & Zyska \& Żakowska 2005 \\
\hline $\begin{array}{l}\text { Rubber, } \\
\text { insulation } \\
\text { materials }\end{array}$ & $\begin{array}{l}\text { Aspergillus sp., Chaetomium sp., Cladosporium } \\
\text { sp., Penicillium sp., Microascus brevicaulis, } \\
\text { Trichoderma sp. }\end{array}$ & Michalski et al. 2001 \\
\hline Plastics & $\begin{array}{l}\text { Aspergillus sp. (A. awamori, A. brasiliensis, } A . \\
\text { flavus, A. terreus), Paecilomyces variotii, } \\
\text { Penicillium sp. (P. expansum, P. ochrochloron), } \\
\text { Talaromyces funiculosus, Trichoderma viride }\end{array}$ & $\begin{array}{l}\text { Żakowska et al. 2003, } \\
\text { Nowak et al. } 2012\end{array}$ \\
\hline $\begin{array}{l}\text { Stone, } \\
\text { concrete, } \\
\text { brick, mortar }\end{array}$ & $\begin{array}{l}\text { Alternaria tenuissima, Aspergillus sp. (A. } \\
\text { brasiliensis, A. fumigatus), Aureobasidium } \\
\text { pullulans, Cladosporium (C. cladosporioides, C. } \\
\text { herbarum), Penicillium sp. (P. chrysogenum, P. } \\
\text { rubrum), Phaeospora sp., Phoma putaminum, } \\
\text { Purpureocillium lilacinum, Trichoderma sp., } \\
\text { Ulocladium consortiale }\end{array}$ & Cwalina 2003 \\
\hline Glass & $\begin{array}{l}\text { Alternaria alternata, Aspergillus sp. } \quad(A . \\
\text { brasiliensis, } A . \quad \text { versicolor }), \quad \text { Talaromyces } \\
\text { funiculosus }\end{array}$ & Sitarz et al. 2003 \\
\hline
\end{tabular}

* Fungal taxa according to Index Fungorum (www.indexfungorum.org, accessed 22.07.2014)

Biodeterioration of building and finishing materials in residential and public buildings is also common. It was estimated that $40 \%$ of people in Poland live and work in buildings with high humidity level $\mathrm{RH}>80 \%$ (European Environmental and Health Information System 2006), and in $20 \%$ of residential houses there are mould-related problems. They not only reduce the aesthetics of the buildings, but also pose a threat to health of residents and workers. Moulds are capable of growing on most construction, finishing and insulation materials used in buildings (Gutarowska 2010). Moulds from genus Aspergillus (A. brasiliensis, A. flavus, A. versicolor), Penicillium ( $P$. chrysogenum, P. expansum), Alternaria and Cladosporium cladosporioides are frequently isolated from buildings. It has been shown that the type of building material significantly modifies mould allergenicity and toxicity (Gutarowska 2013).

Growth of moulds with lipolytic properties such as Cladosporium, Acremonium and Paecilomyces in metalworking fluids or oils constitutes a significant threat in industrial factories. Moulds are able to change the chemical composition of oils and to contribute to biocorrosion of metal surfaces, moreover together with bacteria they produce bioaerosols which are harmful for 
workers (Cyprowski et al. 2007). Some species of Cladosporium and Paecilomyces are able to grow on polymers, rubber and also in the fuels. The processes of degradation of these materials take several months to several years, however, they are the cause of major economic losses, especially due to the destruction of insulations and fuel tanks (Berryman 1987). Studies conducted in Poland showed the presence of moulds in $50 \%$ of samples taken from fuel tanks (Kwiatkowska 2003).
Assessment of strength change of external rubber covers of telecommunication cables revealed $80 \%$ of mass loss caused by growth of actinomycetes (filamentous bacteria) and moulds (Zyska \& Żakowska 2005).

The frequency and scale of the devastation of technical substances and health risks caused by moulds make it necessary to look for new methods of disinfection and protection of materials against biodeterioration.

\section{Protection against mould growth and methods of their elimination from technical materials}

Similarly as in pharmaceutical, cosmetic and food industries also in plants producing technical materials systems of high quality production have been introduced, including high quality of technological water and raw substrates (paper, paints, building materials), as well as cleanliness of equipment, tanks and warehouses for storing both raw materials and products. The microclimate parameters, which should not exceed $\mathrm{RH}<60 \%, 10-15 \%$ humidity of materials (depending on the material) and air temperature in warehouses $18-21^{\circ} \mathrm{C}$ are also monitored.

In the case of textiles, paper, plastics also access to light should be minimized (Abe 2010). However, susceptibility of paper, paints, building materials, wood to harmful impact of microorganisms makes biocide usage during production necessary.

Some examples of biocides and preparations applied to inhibit moulds growth and to produce materials with antifungal properties are presented below (Tab. 2).

Market of chemical substances and preparations (complexes containing biocides and excipients, extending their action) that can be used to protect

industrial materials is regulated by 98/8/EC Directive of the European Parliament and of the Polish Council Act of biocidal products (Dz.U.2002 No. 175, poz. 1433) and the Ordinance of the Minister of Health on the categories and types of biocidal products according to their purpose (Dz.U. 2003 No $16 \mathrm{poz}$ 150) (Brycki 2012).

Selection of a biocide suitable to conserve a given technical material is a big challenge for manufacturers. The main feature of a good biocide is its effectiveness in eliminating different forms of microorganisms (in the case of moulds it is essential to eliminate both mycelium and spores). However, we must remember that biocides added to technical materials must meet a number of additional requirements: they must be non-toxic, non-allergic to animals and humans, they cannot influence properties of the material or permanently adhere to it, must be insensitive to the process parameters, cheap and stable during product life cycle. Taking into account these conditions the choice of a biocide requires cooperation of experts, production technicians, chemists and microbiologists. Also it should be noted that this substance must be biodegradable 
after usage. Common usage of some biocides (such as nanosilver, Triclosan) to produce antimicrobial materials can cause their accumulation in the environment and in organisms, and subsequently elimination of certain organisms which play a crucial ecological role, as well as contribute to the appearance of resistant microorganisms. It is therefore prudent to decide whether addition of a biocide to a technical material is indispensable and use it only in justified circumstances.

Table 2. Selected biocides and preparations with antifungal activity used to protect technical materials against biodeterioration.

\begin{tabular}{|c|c|c|}
\hline Technical material & Biocide / preparation & References \\
\hline Wood & $\begin{array}{l}\text { quaternary ammonium salts, triazols, } \\
\text { boric acid, propiconazol, ionic liquids, } \\
\text { essential oils }\end{array}$ & $\begin{array}{l}\text { Krajewski 2001, } \\
\text { Fojutowski 2003, } \\
\text { Zabielska-Matejuk et al. } \\
2012\end{array}$ \\
\hline Paper & $\begin{array}{l}\text { ethylene oxide, essential oils (thymol), } \\
\text { ozone, phenylacetic acid, quaternary } \\
\text { ammonium salts, isopropanol, ionic } \\
\text { liquids phenylphenol/Irgasan, Nipagin, } \\
\text { Rotanox }\end{array}$ & $\begin{array}{l}\text { Woźniak \& Tymińska } \\
\text { 2003, Karbowska-Berent } \\
\text { et al. } 2009 \text {, Koziróg et } \\
\text { al. } 2012\end{array}$ \\
\hline Textiles & $\begin{array}{l}\text { quaternary ammonium salts, , ethylene } \\
\text { oxide, propylene oxide, salicylanilide, o- } \\
\text { phenylphenol, 5-chlorophenol, } \\
\text { nanosilver and nanocopper / Preventol, } \\
\text { Irgasan }\end{array}$ & $\begin{array}{l}\text { Montegut et al. 1991, } \\
\text { Szostak-Kot 2003, } \\
\text { Abdel-Kareem 2009, } \\
\text { Foksowicz-Flaczyk et al. } \\
\text { 2012, Gutarowska \& } \\
\text { Michalski } 2012\end{array}$ \\
\hline Leather & $\begin{array}{l}\text { 4-chloro-3 methyl phenol, chlorocresol, } \\
\text { 2-phenylphenol, phenoxyethanol, 2-thio- } \\
\text { thiocyano- methyl-benzothiazole, } \\
\text { isothiazoline compounds, } \\
\text { diiodomethyltolyl-sulfone, nanosilver, } \\
\text { nanozinc and nanocopper / Sanitized }\end{array}$ & $\begin{array}{l}\text { Didato \& Yanek 1999, } \\
\text { Orlita 2001, Falkiewicz- } \\
\text { Dulik 2003; } 2012\end{array}$ \\
\hline Petroleum, oil, fuels & $\begin{array}{l}\text { Preventol P109 (2-bromo 2-nitro-1,3 } \\
\text { propanediol and isothiazolones), MAR } \\
71 \text { (N, N'- methylene-bis-5- } \\
\text { methyloxazolidine), Kathon FP1.5 (5- } \\
\text { chloro-2-methyl-4 isothiazolin-2-one } \\
\text { and 2-methyl-4 isothiazolin-3 -one) }\end{array}$ & Kwiatkowska 2003 \\
\hline
\end{tabular}




\begin{tabular}{|l|l|l|}
\hline Technical material & Biocide / preparation & References \\
\hline Paints & $\begin{array}{l}\text { Copper alkylbenzenesulphonate, } \\
\text { quaternary ammonium salts, titanium } \\
\text { dioxide, ionic liquids }\end{array}$ & $\begin{array}{l}\text { Shirakawa } \text { et al. 2002, } \\
\text { Michalczyk \& Cieniecka- } \\
\text { Rosłonkiewicz 2009, } \\
\text { Markowska-Szczupak } \text { et } \\
\text { al. 2012 }\end{array}$ \\
\hline Plastics & nanosilver and nanocopper & Jeziórska et al. 2012 \\
\hline $\begin{array}{l}\text { Stone, concrete, } \\
\text { brick, mortar }\end{array}$ & $\begin{array}{l}\text { quaternary ammonium salts/ Boramon, } \\
\text { Mycetox }\end{array}$ & $\begin{array}{l}\text { Cieniecka-Rosłonkiewicz } \\
\& \text { Komorowska-Kulik } \\
2003, \text { Piontek and Lechów } \\
2012\end{array}$ \\
\hline
\end{tabular}

Disinfection of technical materials which are already biodeteriorated to stop growth of moulds is another important issue. There is a range of methods used to address this problem: laser used for wood (Piotrowska et al. 2003); fumigation with gases (ethylene oxide, propylene oxide), essential oils and nanosilver particles used for paper and textiles (Tymińska 2001, Woźniak \& Tymińska 2003, Gutarowska et al. 2012); gamma radiation used for textiles, paper and leather (Machnowski et al. 2012, Perkowski \& Goździecki 2003, Woźniak \& Tymińska 2003); microwaves for building and finishing materials (Górny et al. 2012); photocatalitic ionization (Pietrzak

\section{References}

Abdel-Kareem, O. 2009. Monitoring, controlling and prevention of the fungal deterioration on museum textiles. V konferencja Rozkład i Korozja mikrobiologiczna materiałów technicznych, Łódź: 64-73.

Abe, K. 2010. Assesment of the environmental conditio in museum storehouse by use of a fungal index. International Biodetrioration and Biodegradation, 64: 32-40.
\& Gutarowska 2013) and biocides (Brycki 2012).

Choosing a method of disinfection one should consider not only the inhibition of fungi growth, but also safety for the technical material. This is particularly important for historical objects. Many of the disinfection methods have a negative impact on the treated materials, they change their strength and optical parameters and may also contribute to their faster biodegradation in the future (Machnowski et al. 2012, Gutarowska et al. 2014). Therefore, it is important to know the effects of disinfection for both microorganisms and for materials to select appropriate process parameters.

Berryman, T.J. 1987. Fuel Quality and demand - an overview. In: Smith R.N. (Ed) Microbiology of fuels, Institute of Petroleum, London.

Błyskal, B. \& Syguła-Cholewińska, J. 2001. Grzyby powodujące deteriorację zabytkowej tkaniny bawełnianej. II konferencja Rozkład i Korozja mikrobiologiczna materiałów technicznych, Łódź: 171-178.

Brycki, B. 2012. Chemiczna ochrona przed biodeterioracją. VI konferencja Rozkład i 
Korozja mikrobiologiczna materiałów technicznych, Łódź: 257-258.

Cieniecka-Rosłonkiewicz, A. \& KomorowskaKulik, J. 2003 Środek do ochrony przed pleśnieniem w pomieszczeniach wilgotnych. III konferencja Rozkład i Korozja mikrobiologiczna materiałów technicznych, Łódź: 382-383.

Cwalina, B. 2003. Korozja kamienia i betonu wzbudzona przez drobnoustroje. III konferencja Rozkład i Korozja mikrobiologiczna materiałów technicznych, Łódź: 38-50.

Cyprowski, M., Piotrowska, M., Zakowska, Z. \& Szadkowska-Stańczyk, I. 2007. Microbial and endotoxin contamination of water-soluble metalworking fluids. International Journal of Occupational Medicine and Environmental Health, 20 (4): 365-371.

Didato, D.T. \& Yanek, S.S. 1999. Fungicides in military leather: an additional option for tanners producing specification leathers. Journal of Amerrican Leather Chemists Association, 94: 45-258.

Falkiewicz-Dulik, M. 2003. Drobnoustroje zasiedlające obuwie oraz ochrona materiałów obuwniczych w aspekcie zdrowotności i biodeterioracji. III konferencja Rozkład i Korozja mikrobiologiczna materiałów technicznych, Łódź: 296-305.

Falkiewicz-Dulik, M. \& Przyjemska, L. 2012. Badania nad poprawą ochrony mikrobiologicznej obuwia dla służb mundurowych. VI konferencja Rozkład i Korozja mikrobiologiczna materiałów technicznych, Łódź: 57-63.

Flannigan, B. \& Miller, J.D. 1994. Health implications of fungi in indoor. In: Samson R.A., Flannigan B., Flannigan M.E., Verhoeff, A.P., Adan, O.C.G., Hoekstra, E.S. (Eds), Health implication of fungi in indoor environments. Elsevier Science, Amsterdam, pp. 3-28.

Florian, M.L. 2004. Fungal Facts, Solving Fungal Problems in Heritage Collections. Archetype Publication Ltd, London.

Florian, M.L. \& Manning, L. 2000. SEM analysis of irregular fungal fox spots in an 1854 book: population dynamics and species identification. International Biodeterioration and Biodegradation, 46: 205-220.
Fojutowski, A. 2003. Aktualne problemy przeciwgrzybowej ochrony drewna. III konferencja Rozkład i Korozja mikrobiologiczna materiałów technicznych, Łódź: 355-366.

Foksowicz-Flaczyk, J., Walentowska, J. \& Bujnowicz, K. 2012. Odporność kompozytów naturalnych zabezpieczonych cieczą jonową na działanie grzybów pleśniowych. VI konferencja Rozkład i Korozja mikrobiologiczna materiałów technicznych, Łódź: 304-308.

Górny, R., Ławniczek-Wałczyk, A., Cyprowski, M. \& Gołofit-Szymczak, M. 2012. Wykorzystanie techniki mikrofalowej w nieinwazyjnym oczyszczaniu budynków z mikrobiologicznych skażeń. VI konferencja Rozkład i Korozja mikrobiologiczna materiałów technicznych, Łódź: 184-191.

Gutarowska, B. 2010. Metabolic activity of moulds as a factor of building materials' biodegradation. Polish Journal of Microbiology, 59 (2): 119-124.

Gutarowska, B. 2013. Moulds and their allergens in buildings. LAP LAMBERT Academic Publishing, Germany.

Gutarowska, B. \& Cichocka, A. 2009. Ocena zanieczyszczenia mikrobiologicznego mas celulozowych oraz wody technologicznej stosowanych w produkcji papieru. Przegląd Papierniczy, 9: 551-555.

Gutarowska, B. \& Czyżowska, A., 2009. The ability of filamentous fungi to produce acids on indoor building materials. Annals of Microbiology, 59 (4): 807-813.

Gutarowska, B. \& Michalski, A. 2012. Microbial degradation of woven fabrics and protection against biodegradation. In: Han-Yong Jeon (Ed) Woven Fabrics. In Tech.

Gutarowska, B., Pietrzak, K., Machnowski, W., Danielewicz, D., Szynkowska, M., Konca, P. \& Surma-Ślusarska, B. 2014. Application of silver nanoparticles for disinfection of materials to protect historical objects. Current Nanoscience, 10(2): 277-286.

Gutarowska, B., Rembisz, D., Zduniak, K., Skóra, J., Szynkowska, M., Gliścinska, E. \& Koziróg, A. 2012. Optimization and application of the misting method with silver nanoparticles for disinfection of the historical objects. 
Biodeterioration\& Biodegradation 75: $167-$ 175.

Jeziórska, R., Zielecka, M., Szadkowska, A., Żakowska, Z. \& Gutarowska, B. 2012. Effect of silica containing immobilized nanosilver on the structure and selected properties of woodfilled high-density polyethylene composites. Journal of Biobased Materials and Bioenergy, 6(4): 1-10,

Karbowska-Berent, J., Kozielec, T., Jarmiłko, J. \& Brycki, B. 2009. Możliwość zastosowania preparatów zawierających czwartorzędowe sole amoniowe do dezynfekcji zabytków na podłożu z papieru. V konferencja Rozkład i Korozja mikrobiologiczna materiałów technicznych, Łódź: 86.

Koziróg, A., Wysocka-Robak, A., Przybysz, K., Żakowska, Z. \& Jeziórska, R. 2012. Materiały techniczne modyfikowane biocydami a ich odporność na rozwój grzybów strzępkowych. VI konferencja Rozkład i Korozja mikrobiologiczna materiałów technicznych, Łódź: 331-335.

Krajewski, K. 2001. Pochodne triazolu jako fungicydy środków ochrony drewna. II konferencja Rozkład i Korozja mikrobiologiczna materiałów technicznych, Łódź: 328-335.

Krumbein, W.E. 1988. Microbial interaction s with mineral materials. In: Houghton D.R., Smith R.N. \& Eggins H.O.W., (Eds) Biodeterioration 7, Elsevier Applied Science, Barking.

Kwiatkowska, D. 2003. Skażenie mikrobiologiczne ropy naftowej i produktów naftowych. III konferencja Rozkład i Korozja mikrobiologiczna materiałów technicznych, Łódź: 28-37.

Larsen, T.O. \& Frisvad, J.C. 1994. Production of volatiles and presence of common indoor Penicillia and Aspergilli. Health implications of fungi in indoor environments. Air quality monographs, vol 2. Elsevier.

Machnowski, W., Gutarowska, B., Perkowski, J. \& Wrzosek, H. 2012 Effects of gamma radiation on the mechanical properties of and susceptibility to biodegradation of natural fibers. Textile Research Journal, 83(1): 44-55.

Markowska-Szczupak, A., Ulfig, K. \& Morawski, A. 2012. Wpływ ditlenku tytanu aktywowanego światłem widzialnym na wzrost grzybów pleśniowych. VI konferencja Rozkład i Korozja mikrobiologiczna materiałów technicznych, Łódź: 293.

May E., Lewis F.J., Pereira S., Tayler S., Seaward M.R.D. \& Allsop D. 1993. Microbial deterioration of building stone - a review. Biodeterioration, 7: 109-123

Michalczyk, A. \& Cieniecka-Rosłonkiewicz, A. 2009. Badania nad wykorzystaniem cieczy jonowych jako konserwantów do farb emulsyjnych. V konferencja Rozkład i Korozja mikrobiologiczna materiałów technicznych, Łódź: 142.

Michalski, J., Falkowski, J. \& Jakubowska, B. 2001. Skutki eksploatacyjne ataku grzybów pleśniowych na elementy tworzywowe wyrobów technicznych. II konferencja Rozkład i Korozja mikrobiologiczna materiałów technicznych, Łódź: 228-234.

Montegut, D., Indictor, N. \& Koestler, R.J. 1991. Fungal deterioration of cellulosic textiles: a review. International Biodeterioration $28(1-4)$ : 209-226.

Nowak, B., Pająk, J. \& Karcz, J. 2012. Udział wybranych grzybów mikroskopowych w rozkładzie polietylenu modyfikowanego skrobią. VI konferencja Rozkład i Korozja mikrobiologiczna materiałów technicznych, Łódź: 80-85.

Orlita, A. 2001. Microbial biodeterioration of leather and its control. II konferencja Rozkład i Korozja mikrobiologiczna materiałów technicznych, Łódź: 41-54.

Perkowski, J. \& Goździecki, T. 2003. Zastosowanie promieniowania jonizujacego do dezynfekcji obiektów muzealnych. III konferencja Rozkład i Korozja mikrobiologiczna materiałów technicznych, Łódź: 202-207.

Pietrzak, K. \& Gutarowska, B. 2012. The effectiveness of photocatalyticionisation disinfection of filter materials. Polish Journal of Microbiology, 62(2): 131-139.

Piontek, M. \& Lechów, H. 2012. Ocena skuteczności biocydów w zastosowaniach zewnętrznych w budownictwie. VI konferencja Rozkład i Korozja mikrobiologiczna materiałów technicznych, Łódź: 273-278.

Piotrowska, M., Bogusławska-Kozłowska, J. \& Rożniakowski, K. 2003. Usuwanie grzybów pleśniowych z drewna z zastosowaniem lasera. III konferencja Rozkład i Korozja 
mikrobiologiczna materiałów technicznych, Łódź: 155-158.

Shirakawa, M.A., Gaylarde, C.C., Gaylarde, P.M., John, V. \& Gambale, V. 2002. Fungal colonization and succession on newly painted buildings and the effect of biocide. FEMS Microbial Ecology, 39:165-173.

Singh, J. 2001. Occupational exposure to moulds in buildings. Indoor Built Environment, 10: 172178.

Singh, J. 2005. Toxic moulds and indoor air quality. Indoor Built Environment, 14: 229-234.

Sitarz, M., Żakowska, Z. \& Kuberski, S. 2003. Biodeterioracja szkła optycznego. III konferencja Rozkład i Korozja mikrobiologiczna materiałów technicznych, Łódź: 90-92.

Strzelczyk, A., Fedrizzi-Szostok, A. \& KarbowskaBerent, J. 2003. Mikrobiologiczne zniszczenia zabytków ze skór wyprawionych glinowo. III konferencja Rozkład i Korozja mikrobiologiczna materiałów technicznych, Łódź: 194-201.

Strzelczyk, B. 2001. Zmiany estetyczne i strukturalne wywołane w zabytkach przez drobnoustroje. II konferencja Rozkład i Korozja mikrobiologiczna materiałów technicznych, Łódź: 28-40.

Szostak-Kot, J. 2001. Mikrobiologiczny rozkład tkanin. II konferencja Rozkład i Korozja mikrobiologiczna materiałów technicznych, Łódź: 55-62.
Szostak-Kot, J. 2003. Mikrobiologia tkanin zabytkowych. III konferencja Rozkład i Korozja mikrobiologiczna materiałów technicznych, Łódź: 171-178.

Tymińska, A. 2001. Dezynfekcja zbiorów przy pomocy komory na tlenek etylenu w Bibliotece Narodowej w Warszawie. II konferencja Rozkład i Korozja mikrobiologiczna materiałów technicznych, Łódź: 324-327.

Woźniak, M. \& Tymińska, A. 2003. Mikrobiologiczne aspekty konserwacji starodruków. III konferencja Rozkład i Korozja mikrobiologiczna materiałów technicznych, Łódź: 186-193.

Zabielska-Matejuk, J., Pernak, J., Frąckowiak, I., Jóżwiak, M., Andrzejak, C., Stangierska, A. \& Przybylska, W. 2012. Odporność na podstawczaki i pleśnie drewna, płyt wiórowych i sklejek zabezpieczonych mieszaninami cieczy jonowych $\mathrm{z}$ pochodnymi 1,2,4 triazolu. VI konferencja Rozkład i Korozja mikrobiologiczna materiałów technicznych, Łódź: 279-286.

Zyska, B. 2001. Katastrofy, awarie i zagrożenia mikrobiologiczne w przemyśle i budownictwie. Wyd. Politechniki Łódzkiej, Łódź

Zyska, B. \& Żakowska, Z. 2005. Mikrobiologia materiałów. Politechnika Łódzka, Łódź

Żakowska, Z., Stobińska, H., Ratajska, M., Boryniec, S. \& Ślusarczyk, C. 2003. Biodegradacja wielowarstwowego opakowania Tetra-Pack. III konferencja Rozkład i Korozja mikrobiologiczna materiałów technicznych, Łódź: 108-113.

\section{Streszczenie}

Pleśnie są mikroorganizmami, które odgrywają kluczową rolę w biodeterioracji materiałów technicznych, co wynika $\mathrm{z}$ ich cech fizjologicznych i metabolizmu. Materiał techniczny stanowi dla nich albo źródło węgla i energii (drewno, papier, tekstylia, paliwa, skóra) albo jest podłożem do ich wzrostu (cegły, kamień, metal, szkło). Grzyby charakteryzujące się wysoką aktywnością biodeterioracyjną enzymatyczną i kwasotwórczą należą głównie do Aspergillus, Penicillium, Trichoderma, Cladosporium, Paecilomyces i Chaetomium. Przedstawiciele niektórych rodzajów grzybów (oprócz wymienionych powyżej, również m.in. Stachybotrys, Alternaria, Cladosporium, Epidermophyton, Microsporum, Scopulariopsis, Trichophyton) rosnąc na substancji technicznej oraz wytwarzając alergeny i mykotoksyny stwarzają zagrożenia zdrowotne. Dlatego na podstawie wiedzy na temat warunków rozwoju pleśni i mechanizmów biodeterioracji należy odpowiednio zabezpieczać materiały przed rozwojem grzybów. Istotne jest również poszukiwanie nowych, bezpiecznych dla materiałów technicznych metod dezynfekcji w celu zahamowania rozwoju grzybów. Zastosowanie biocydów w celach ochronnych należy 
ograniczyć jedynie do materiałów najbardziej narażonych na biodeteriorację (papier, tekstylia, paliwa, farby), mając na uwadze aspekty ochrony środowiska, a także produkcję materiałów biodegradowalnych, zapewniając cykl życia produktu. 